\title{
Polyphenols of selected peach and plum genotypes reduce cell viability and inhibit proliferation of breast cancer cells while not affecting normal cells
}

\author{
Marcia Vizzotto ${ }^{\mathrm{a}, \mathrm{c}}$, Weston Porter ${ }^{\mathrm{b}}$, David Byrne ${ }^{\mathrm{c}}$, Luis Cisneros-Zevallos ${ }^{\mathrm{c}, *}$ \\ ${ }^{a}$ Embrapa Clima Temperado, BR 392, km 78, 96001-970 Pelotas, RS, Brazil ${ }^{1}$ \\ ${ }^{\mathrm{b}}$ Veterinary Integrative Biosciences, Texas A\&'M University, College Station, TX 77843, United States \\ ${ }^{\mathrm{c}}$ Dpt of Horticultural Sciences and Vegetable E Fruit Improvement Center, Texas AEM University, College Station, TX 77843, United States
}

\section{A R T I C L E I N F O}

\section{Article history:}

Received 24 February 2014

Received in revised form 2 May 2014

Accepted 12 May 2014

Available online 20 May 2014

\section{Keywords:}

Breast cancer

Polyphenols

Selective cytotoxicity

Prunus persica

Prunus salicina

Apoptosis

\begin{abstract}
A B S T R A C T
Polyphenolic extracts and fractions of selected peach and plum genotypes were evaluated for cell viability and antiproliferation activity in vitro against an estrogen independent MDA-MB-435 and estrogen dependent MCF-7 breast cancer cell lines and one non-cancerous breast line MCF-10A. All extracts showed a phenolic dose-dependent cytotoxic effect against MDA-MB-435, weak activity against MCF-7 and small or no activity against MCF-10A. Genotype phenolic profiles showed varying degrees of polyphenolic mixtures. Fractionation of peach BY00P6653 extracts gave 4 fractions, with fraction F-I (caffeic acid derivatives) showing a strong activity against MDA-MB-435 followed by fraction F-II (anthocyanins). Induced-apoptosis by F-I on MDA-MB-435 was confirmed by Tunnel nuclear staining of cells with apoptotic DNA fragmentation $(0-100 \mu \mathrm{g} / \mathrm{mL})$ with no effects in normal cells $(0-200 \mu \mathrm{g} / \mathrm{mL})$. Selected stone fruit genotypes can be added to the list of fruits with cytotoxic effects against breast cancer cells while not affecting normal cells.
\end{abstract}

(c) 2014 Elsevier Ltd. All rights reserved.

\section{Introduction}

Multiple factors contribute to the development of human breast cancer; however, environmental factors, especially diet, appear to have a great effect. Studies have shown that women in industrialized countries consuming a high-fat diet are more likely to have breast cancer than women in populations that consume a low-fat diet like in Asian countries (Parkin, 2004; Pasqualini, 2004). Fruit and vegetable consumption provide an array of bioactive phytochemicals which can help lower cancer risk (Hertog et al., 1995).

The anticancer activity of many fruit extracts have been studied using in vitro cell line model systems. For example, a flavonol fraction from cranberry inhibited proliferation of the estrogen independent MDA-MB-435 human breast tumour cell line by blocking cell cycle progression and inducing apoptosis (Ferguson, Kurowska, Freeman, Chambers, \& Koropatnick, 2004). Ripe fruits of Solanum nigrum inhibited cell growth and induced cell death by apoptosis in estrogen dependent MCF-7 human breast cancer cell (Son et al., 2003). Phenolics from Terminalia chebulia fruits

\footnotetext{
* Corresponding author. Tel.: +1 979845 3244; fax: +1 9798450627.

E-mail address: lcisnero@tamu.edu (L. Cisneros-Zevallos).

1 Present address.
}

decreased cell viability, inhibited cell proliferation, and induced cell death of MCF-7 breast cancer cell (Saleem, Husheem, Harkonen \& Pihlaja, 2002). Red wine flavonoids show selective cytotoxicity in breast cancer cells and a marginal effect on normal cells (Hakimuddin, Paliyath \& Meckling, 2004) while whole apple extract inhibits mammary cancer growth in vivo (Liu, Liu \& Chen, 2005). However, little information has been published related to the antitumour properties of peach and plum fruit. Previous studies have shown that plum extracts suppressed growth and induced apoptosis on human hepatoma cell line (HepG2) (Ramos, Alia, Bravo \& Goya, 2005) and HT-29 and MCF-7 cell lines (Olsson, Gustavsson, Andersson, Nilsson, \& Duan, 2004). Peach extracts in in vivo studies reduce micronuclei induction in bone marrow cells by $43-50 \%$ confirming its protective effect (Edenharder, Krieg, Kottgen \& Platt, 2003). More recently, prune extracts (Prunus domestica L.) were shown to suppress proliferation and induce apoptosis in Caco-2 colon cancer cells (Fujii, Ikami, Xu \& Ikeda, 2006).

In general, these different plant species have compounds that are active against cancer proliferation by blocking cell cycle progression and/ or inducing apoptosis which is directly associated to DNA fragmentation. Selective cytotoxicity against cancer cells while not affecting normal cell is a desired feature of these bioactive compounds. Many phenolics have been reported in stone 
fruits such as anthocyanins, hydroxycinnamates, flavan 3-ols and flavonols, predominantly chlorogenic acid, neo-chlorogenic acid, catechin, epicatechin, and quercetin 3-rutinoside (Kim, Chun, Kim, Moon, \& Lee, 2003; Tomas-Barberan et al., 2001). Many of these phenolics act as antioxidants (Kim et al., 2003), antimutagenics (Miyasawa \& Hisama, 2003), and anticarcinogenics (Kamei et al., 1995).

In the present study we examined whether selected peach (Prunus persica) and plum (Prunus salicina) genotype extracts and phenolic fractions affected cell viability and proliferation on estrogen dependent MCF-7 and estrogen independent MDA-MB-435 human cancer cell lines compared to a non-cancerous breast cell line MCF-10A. In addition, we identified the bioactive phenolic compounds and showed evidence of apoptosis induction in the cytotoxic effect.

\section{Materials and methods}

\subsection{Chemicals, standards and reagents}

The anthocyanin standards cyanidin-3-glucoside and cyanidin3-galactoside were purchased from Polyphenols Laboratories AS (Sandness, Norway). Phenolic standards such chlorogenic acid, caffeic acid, quercetin, rutin and Folin-Ciocalteu reagent, sodium carbonate $\left(\mathrm{Na}_{2} \mathrm{CO}_{3}\right)$, Trolox and 2,2-diphenyl-1-picrylhydrazyl (DPPH) MTT, acetonitrile, methanol, DMEM, and other chemicals such as sodium hydroxide, potassium hydroxide were purchased from Sigma Chemical Co. (St. Louis, MO).

\subsection{Extraction of phenolic compounds}

The peach and plum varieties were from the breeding programs at Texas A\&M University (College Station, TX, USA) and the USDA (Parlier, CA and Byron, GA, USA). Fruits from four peach varieties (Flameprince, BY00P4555, BY00P6653, and BY98P5369) and three plum varieties (Byrongold, Black Splendor, and Burgundy) were extracted and analyzed. One-hundred g of fresh tissue (flesh plus skin) was homogenized with $300 \mathrm{~mL}$ of methanol. Tubes were capped and stored overnight at $2-4{ }^{\circ} \mathrm{C}$ and then centrifuged at $29,000 \mathrm{~g}$ for $20 \mathrm{~min}$ at $2{ }^{\circ} \mathrm{C}$ (Mod. J10-6, Beckman Instruments Inc., Fullerton, CA, USA). The supernatant was evaporated in a rotavapor (Büchi, Flawil, Switzerland) at $40^{\circ} \mathrm{C}$ under $240 \mathrm{mbar}$ pressure until dryness and re-suspended in nanopure water. Samples were frozen at $-80^{\circ} \mathrm{C}$ and freeze-dried (FTS ${ }^{\circledR}$ Systems, Inc., Stone Ridge, NY, USA) at $-50{ }^{\circ} \mathrm{C}$ and $200 \mu \mathrm{Hg}$ of pressure. These samples were denominated "crude extract" and were used for further fractionation of the phenolic compounds.

\subsection{Fractionation of the phenolic compounds}

The fractionation of the phenolic compounds was based on the procedure described by Oszmianski et al. (1988) (Fig. 1(I)). Three grams of freeze dried sample were mixed thoroughly in $200 \mathrm{~mL}$ of nanopure water and adjusted to $\mathrm{pH} 7.0$ with $5 \mathrm{M} \mathrm{NaOH}$. The extract was loaded in SEP Pack C18 cartridge previously conditioned to pH 7.0 with $50 \mathrm{~mL}$ of $100 \%$ methanol and $50 \mathrm{~mL}$ of nanopure water $(\mathrm{pH}$ 7.0). The neutral phenolics were absorbed in the cartridge while the phenolic acids were not. The cartridge was washed with $50 \mathrm{~mL}$ of water $\mathrm{pH}$ 7.0. The wash water was combined with the phenolics that were not adsorbed in the cartridge and adjusted to $\mathrm{pH} 2.0$. This mixture of compounds was loaded into a second cartridge previously conditioned at pH 2.0 with $50 \mathrm{~mL}$ $100 \%$ methanol and $50 \mathrm{~mL}$ nanopure water $\mathrm{pH} 2.0$. Phenolic acid compounds bounded to the matrix of the second cartridge and were later eluted with $50 \mathrm{~mL}$ 100\% methanol (F-I). After adjusting the $\mathrm{pH}$ to 2.0 in the first cartridge, elution of anthocyanins monomers, procyanidins and catechins was accomplished by passing $50 \mathrm{~mL}$ of $16 \%$ acetonitrile at $\mathrm{pH} 2.0$ (F-II). The flavonols were eluted using $50 \mathrm{~mL} 100 \%$ ethyl acetate (F-III) and the anthocyanin polymers using $50 \mathrm{~mL}$ of $100 \%$ methanol (F-IV).

\subsection{Total phenolics and HPLC phenolic profiles}

Total phenolics were quantified in the different genotypes and the fractions by the Folin-Ciocalteu method (Cevallos-Casals \& Cisneros-Zevallos, 2003). A $0.05 \mathrm{~g}$ freeze-dried sample was mixed with $5 \mathrm{~mL}$ of methanol in a screw-cap tube using a vortex mixer. A $0.5 \mathrm{~mL}$ aliquot of samples were taken from the prepared sample and diluted with $8 \mathrm{~mL}$ of nanopure water. At the same time, a blank containing $0.5 \mathrm{~mL}$ of methanol was equally diluted and analyzed. Each sample and blank were combined with $0.5 \mathrm{~mL}$ of $0.25 \mathrm{~N}$ Folin-Ciocalteu reagent, and allowed to react for 3 min before the addition of $1 \mathrm{~mL} 0.5 \mathrm{M} \mathrm{Na}_{2} \mathrm{CO}_{3}$. The reaction mixture was incubated for $2 \mathrm{~h}$ at room temperature and measurements of absorbance at $725 \mathrm{~nm}$ were taken. The spectrophotometer was set to zero absorbance using the blank. Measurements were taken in a quartz cuvette. The concentration of total phenolics was estimated from a chlorogenic acid standard curve and expressed as chlorogenic acid equivalent.

The identification of the phenolic profiles present in the crude extracts and fractions was performed by using HPLC-PDA analysis with the following characteristics: binary Waters 515 HPLC (Milford, MA, USA) pump system, Waters 717 plus auto sampler automated gradient controller, SP8792 temperature controller and Waters 996 Photodiode array detector. For peak integration Millenium32 software from Waters was used. Phenolics were separated by an Atlantis ${ }^{\mathrm{TM}} \mathrm{C} 185 \mu \mathrm{m}, 4.6 \mathrm{~mm} \times 150 \mathrm{~mm}$ column and a $4.6 \mathrm{~mm} \times 20 \mathrm{~mm}$ guard column using a gradient elution at a flow rate of $1 \mathrm{~mL} \mathrm{~min}{ }^{-1}$ for $30 \mathrm{~min}$. The mobile phase consisted of acidified nanopure water at $\mathrm{pH} 2.3$ with $\mathrm{HCl}(\mathrm{A})$ and acetonitrile $\mathrm{HPLC}$ grade (B). The elution was isocratic conditions from 0 to $5 \mathrm{~min}$ with $85 \% \mathrm{~A}$ and $15 \%$ B. Gradient from 5 to 30 min began with $85 \% \mathrm{~A}$ and $15 \% \mathrm{~B}$ and ended with $0 \% \mathrm{~A}$ and $100 \% \mathrm{~B}$. followed by isocratic conditions from 30 to $35 \mathrm{~min}$ with $0 \% \mathrm{~A}$ and $100 \% \mathrm{~B}$ to re-equilibrate the column. Column temperature was maintained at $35^{\circ} \mathrm{C}$. The injection volume was $10 \mu \mathrm{L}$. The identification of peaks was based on retention time and the spectra of external standards. Caffeic acid derivative was identified after basic hydrolysis of fraction I. Fraction I sample was hydrolyzed with $\mathrm{NaOH} 4 \mathrm{M}$ for $16 \mathrm{~h}$ after being flushed with $\mathrm{N}_{2}$. Hydrolysis was stopped with $\mathrm{HCl} 6 \mathrm{M}$ until sample changed colour. A sample was injected into the HPLC. The concentration of phenolic compounds was determined from standard curves constructed for individual compounds by injecting different concentrations of corresponding standards.

\subsection{Antioxidant activity}

Antioxidant activity was quantified by the DPPH (2,2-diphenyl1-picrylhydrazyl) radical method (Cevallos-Casals \& CisnerosZevallos, 2003). A $0.05 \mathrm{~g}$ of freeze-dried sample was mixed with $5 \mathrm{~mL}$ of methanol in a screw-cap tube using a vortex mixer. Before running the reaction, the spectrophotometer was blanked with methanol, and DPPH was diluted with methanol from a mother solution to reach an absorbance of $1.1 \mathrm{AU}$ at $515 \mathrm{~nm}$. $150 \mu \mathrm{L}$ of sample was combined with $2850 \mu \mathrm{L}$ of the DPPH solution. A blank was simultaneously prepared with $150 \mu \mathrm{L}$ methanol. Samples and blank were left to react for $24 \mathrm{~h}$. Measurements of absorbance were taken with a quartz cuvette at $515 \mathrm{~nm}$. Antioxidant activity was estimated as equivalents of Trolox (6-hydroxy-2,5,7,8-tetramethylchroman-2-carboxylic acid) by comparison to a standard curve. 
(I)

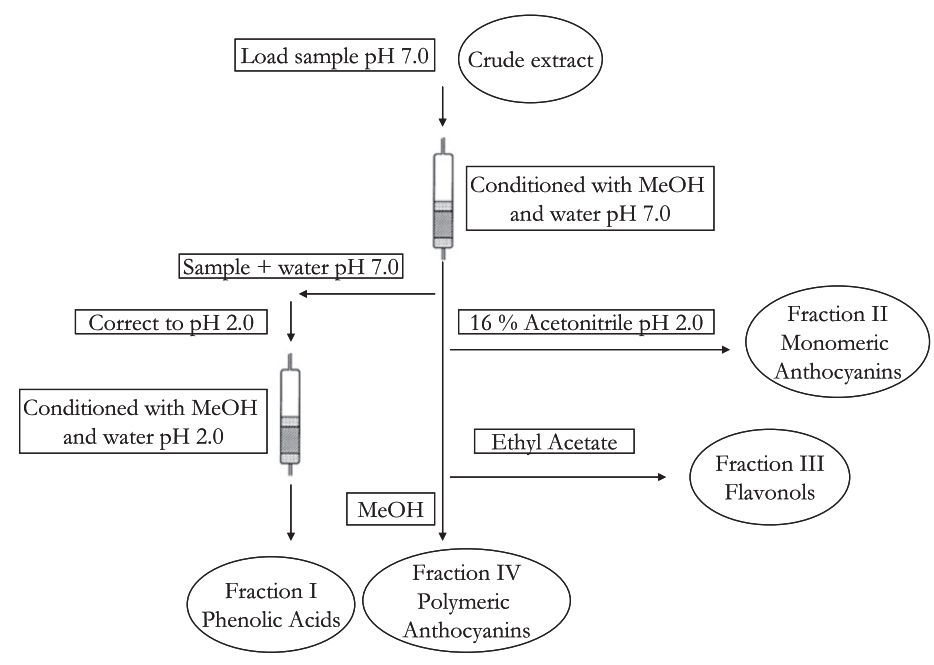

(II)

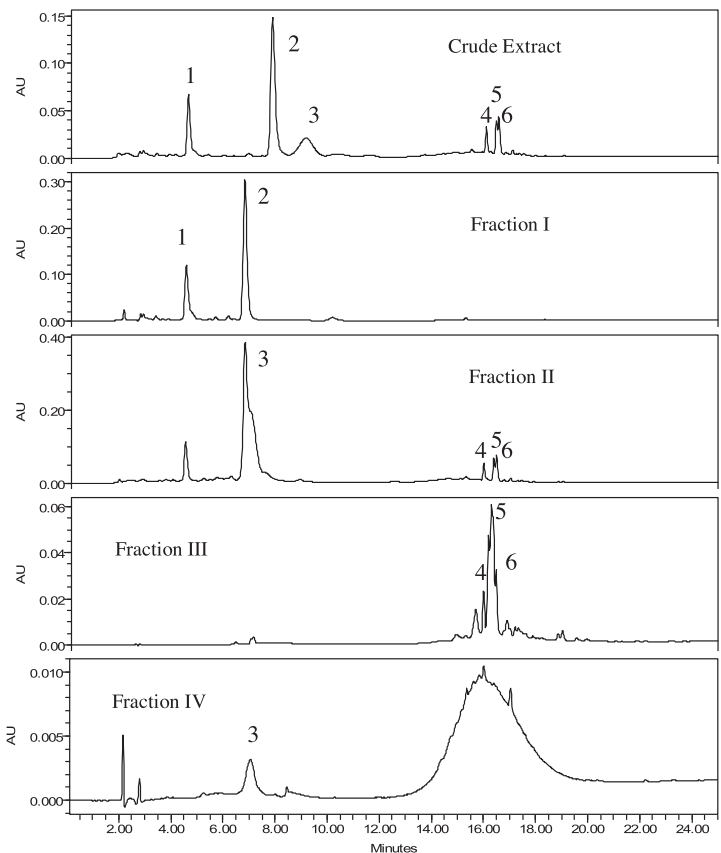

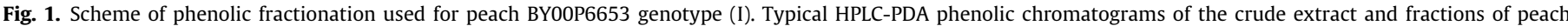

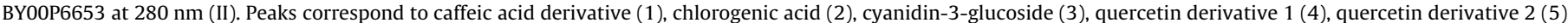
and quercetin derivative 3 (6)

\subsection{Cell lines and cell culture}

MCF-7, the estrogen-positive human breast cancer was cultured in Petri dishes using Dulbecco's modified Eagle's medium (DMEM) supplemented with $2.5 \%(\mathrm{v} / \mathrm{v})$ stripped fetal bovine serum (FBS) high glucose, L-glutamine, $25 \mathrm{nM}$ HEPES buffer, pyridoxine hydrochloride, without sodium pyruvate and without phenol red (Gibco ${ }^{\mathrm{TM}}$ Invitrogen Corp., Grand Island, NY, USA) at $37^{\circ} \mathrm{C}$ in a $5 \%$ $\mathrm{CO}_{2}$ atmosphere. MDA-MB-453, the estrogen-negative human breast cancer was cultured in Petri dishes using Dulbecco's modified Eagle's medium (DMEM) supplemented with $10 \%(\mathrm{v} / \mathrm{v})$ fetal bovine serum (FBS), 1\% strippicin- penicillin antibiotic mix, with L-glutamine, $4.5 \mathrm{~g} / \mathrm{L}$ glucose and without sodium pyruvate (Biowhittaker ${ }^{\mathrm{TM}}$ Cambrex Bioscience Walkersville Inc., Walkersville, $\mathrm{MD}, \mathrm{USA}$ ) at $37^{\circ} \mathrm{C}$ in a $5 \% \mathrm{CO}_{2}$ atmosphere. MCF-10A, the non-cancerous breast cell line was cultured in Petri dishes using Dulbecco's modified Eagle's medium/F12 (DME/F12) supplemented with 5\% $(\mathrm{v} / \mathrm{v})$ fetal bovine serum (FBS), $1 \%$ strippicin- penicillin antibiotic mix, $1 \mathrm{~mL}$ EGF $(10 \mu \mathrm{g} / \mathrm{ml}), 5 \mathrm{~mL}$ insulin $(1 \mathrm{mg} / \mathrm{mL}), 250 \mu \mathrm{l}$ hydrocortisone $(1 \mathrm{mg} / \mathrm{mL})$, and $20 \mu \mathrm{L}$ Cholera toxin $\left(\mathrm{Gibco}^{\mathrm{TM}}\right.$, Invitrogen Corp., Grand Island, NY, USA) at $37{ }^{\circ} \mathrm{C}$ in a $5 \% \mathrm{CO}_{2}$ atmosphere.

\subsection{Cell viability assay}

Antiproliferation was measured in the presence and absence of treatments by using MTT [3-(4,5-dimethylthiazolyl-2)-2,5-diphenyltetrazolium bromide] or methyl thiazol tetrazolium assay (Mosmann, 1983) based on its conversion to MTT-formazan. Cells were seeded in 96-well microtitre plates at a density of 7000 cells per well. After $12-24 \mathrm{~h}$ period of incubation to allow cell attachment, cells were exposed to varying concentrations of peach and plum extracts for $24 \mathrm{~h}$. The concentrations used for all the genotypes and fractions were based on total phenolic content and expressed as $\mu \mathrm{g}$ of chlorogenic acid $/ \mathrm{mL}$. After the appropriate incubation period, $100 \mu \mathrm{L}$ of MTT $(5 \mathrm{mg} / \mathrm{mL})$ was added per well and incubated for $1 \mathrm{~h}$ at $37^{\circ} \mathrm{C}$. After incubation, MTT was aspirated and $100 \mu \mathrm{L}$ of dimethyl sulfoxide (DMSO) was added to lyse the cells and dissolve the blue formazan crystals. Cell viability was calculated according to the following equation.

Cell viability $(\%)=\left[\mathrm{OD}_{1}-\mathrm{OD}_{3} / \mathrm{OD}_{2}-\mathrm{OD}_{3}\right] \times 100$

where OD is the optical density of cell culture with sample $\left(\mathrm{OD}_{1}\right)$, without sample $\left(\mathrm{OD}_{2}\right)$ and of the medium $\left(\mathrm{OD}_{3}\right)$ measured by spectrophotometer at $570 \mathrm{~nm}$. The $\mathrm{IC}_{50}$ value (phenolic concentration needed to reduce proliferation in 50\%) was determined from a linear equation passing through two points in each curve that were within the $50 \%$ reduction values.

\subsection{Antiproliferation assay}

Cell growth determination was performed using an electronic counter (Z1 Coulter). Ten thousand cells per well were seeded in 6 -well plate and incubated for $24 \mathrm{~h}$ to allow cell attachment before exposure to varying concentrations of extracts. After the appropriate incubation period, the medium was aspirated and the cells rinsed with $1 \mathrm{~mL}$ of PBS (phosphate saline buffer). After incubation period of 5 min with $200 \mu \mathrm{L}$ of trypsin, $800 \mu \mathrm{L}$ of medium were added and the mix was transferred to a vial previously filled with $19 \mathrm{~mL}$ of isotone II solution. Two readings were taken from each replication. The results were expressed as number of cells.

\subsection{Terminal Deoxynucleotidyl Transferase-mediated dUTP nick and labeling (TUNEL) assay}

To detect apoptotic cells, in situ ending of labeling of the 3-OH end of the DNA fragments generated by apoptosis was performed using the terminal transferase, recombinant kit (Roche, Penzberg, Germany). Cells were grown in culture chamber slides (Falcon ${ }^{\circledR}$, Becton Dickinson Labware, Franklin Lakes, NJ, USA) and treated with fraction I for $12 \mathrm{~h}$. The cells were washed in $500 \mu \mathrm{L}$ of 
phosphate-buffer saline PBS $(0.138 \mathrm{M} \mathrm{NaCl}, 0.0027 \mathrm{M} \mathrm{KCl}$ at $\mathrm{pH}$ 7.4) and fixed by addition of $300 \mu \mathrm{L}$ of $4 \%$ paraformaldehyde for $15 \mathrm{~min}$ at $4{ }^{\circ} \mathrm{C}$. They were then washed twice in fresh PBS for 5 min. Cells were permeablized by $0.2 \%$ Triton X-100 solution in PBS for 5 min., washed 5 times for $5 \mathrm{~min}$ in fresh PBS and stored at $4{ }^{\circ} \mathrm{C}$ until further analyses. Then the slides were covered by $200 \mu \mathrm{L}$ of equilibration buffer $\left(\mathrm{CoCl}_{2}\right.$ diluted in TE buffer) for 10 min. Two hundred microlitres of Terminal Deoxynucleotidyl Transferase (TdT) reaction mix were added to the slide and incubated at $37^{\circ} \mathrm{C}$ for $60 \mathrm{~min}$ for the end-labeling reaction to occur. The reaction was ended by adding SSC sodium chloride-sodium citrate buffer to the slide for $15 \mathrm{~min}$. The slides were washed 5 times for $5 \mathrm{~min}$ in fresh PBS. After washing, the slides were mounted with Vectashield mounting medium for fluorescence with $4^{\prime}$, 6-diamidino-2-phenylindole (DAPI) staining (Vector Laboratories, Inc., Burlingame) and examined with a fluorescent microscope.

\subsection{Statistical analysis}

Quantitative data represent mean values with the respective standard deviation values corresponding to 3 replicates. SPSS software (SPSS Inc. 2002) was used for all specific statistical analysis applying ANOVA and Duncan's test $(p \leqslant 0.05)$.

\section{Results and discussion}

\subsection{Total phenolics and antioxidant activity}

Results showed a broad range of phenolic content per $g$ of freezedried sample ( $\sim 6.5$-fold) and antioxidant activity ( $\sim 5.5$-fold $)$ for the selected peach and plum varieties studied (Table 1 ). The phenolic content of peach varieties followed the order BY00P6653> BY98P5369 > Flameprince $>$ BY00P4555, while for plum varieties the order was Black Splendor $>$ Burgundy $>$ Byrongold. The antioxidant activity (AOX) of peach and plum varieties followed similar order as phenolic content, however in peaches, Flameprince $\sim$ BY00P4555 and in plums, Burgundy Byrongold. In general, redfleshed varieties showed higher phenolic and antioxidant activity than yellow- or white-fleshed varieties. Interestingly, the specific AOX (expressed on phenolic basis) which is the antioxidant activity of the mixture of phenolics present in each type of fruit was similar for all varieties ( $\sim 1098 \mu \mathrm{g}$ Trolox/mg phenolics) suggesting similar radical scavenging properties. In previous work it was shown that in different peach and plum varieties the specific AOX tended to be similar between plum varieties (average $\sim 750$ and range of $300-1400 \mu \mathrm{g}$ Trolox/mg phenolics) and of a broader range values between peach varieties (average $\sim 800$ and range of $250-2200 \mu \mathrm{g}$ Trolox/mg phenolics) (Vizzotto, Cisneros-Zevallos, Byrne, Ramming, \& Okie, 2007).

\subsection{Cell viability and $I C_{50}$ values of extracts}

Results showed that peach and plum crude extracts had cytotoxic effects on both breast cancer cell lines and this effect was concentration dependent (Fig. 2(I)). The crude extracts dramatically reduced cell viability of the estrogen independent MDAMB-435 cell line at phenolic concentrations of $\leqslant 100 \mu \mathrm{g} / \mathrm{mL}$ after an incubation period of $24 \mathrm{~h}$ (Fig. 2(IA)). Calculated $\mathrm{IC}_{50}$ values for the crude extracts on the MDA-MB-435 cell line showed two distinct groups, one for the red-fleshed BY00P6653 peach and Burgundy plum fruits $(\sim 32.5 \mu \mathrm{g} / \mathrm{mL})$ and another for the other varieties studied $(\sim 75 \mu \mathrm{g} / \mathrm{mL})$ (Table 1$)$.

The crude extracts showed a biphasic effect on cell viability of the estrogen dependent MCF-7 cell line (Fig. 2(IB)). There was a slight increase in cell viability at low phenolic concentrations and a reduction in cell viability at higher concentrations. Calculated $\mathrm{IC}_{50}$ values for the crude extracts on the MCF-7 cell line were higher than those of the MDA-MB-435 cell line and very similar among each of the selected varieties studied $(\sim 435 \mu \mathrm{g} / \mathrm{mL})$. Only the Burgundy plum and BY00P4555 peach were not cytotoxic to the estrogen dependent MCF-7 breast cancer cell line (Table 1). In preliminary experiments the estrogen dependent MCF-7 cells were treated with estrogen and no further reduction in cell viability was observed when exposed to peach and plum crude extracts, suggesting phenolics did not interfere with estrogen receptor activity (data not shown).

The fruit crude extracts were not cytotoxic to the normal breast MCF-10A cell line (Fig. 2(IC)) and with most crude extract treatments there was an increase in cell viability. The only exceptions were a reduction in cell viability caused by Byrongold plum ( $\sim 25 \%)$ and BY00P6653 peach ( $50 \%)$ extracts at very high phenolic concentrations $(\sim 500 \mu \mathrm{g} / \mathrm{mL})$, however, within the range $0-375 \mu \mathrm{g} / \mathrm{mL}$ these genotype extracts were not cytotoxic. These results indicate that the peach and plum varieties preferentially reduced cell viability and were cytotoxic to the MDA-MB-435 cell line which is a very aggressive and invasive breast cancer cell line as well as the less invasive MCF-7 cell line, while not affecting the normal breast cell line MCF-10A. Most breast cancers are heterogeneous and consist of estrogen dependent and independent cancer cells. Extracts that may inhibit both cancer cell lines and have little or no affect on normal cells would be of great interest.

\subsection{Cell viability, $I C_{50}$ values and antiproliferation activity of phenolic fractions of the BY00P6653 peach}

Fractionation of BY00P6653 peach extracts allowed the separation of phenolic compounds into different families including phenolic acids (F-I), anthocyanins (F-II), other flavonoids (F-III), and polymerized compounds (F-IV). The phenolic content and AOX

Table 1

Phenolic content, antioxidant activity and cell viability effects of different peach and plum genotype extracts.

\begin{tabular}{|c|c|c|c|c|c|c|c|}
\hline \multirow[t]{2}{*}{ Genotypes } & \multirow[t]{2}{*}{ Fresh colour } & \multirow[t]{2}{*}{ Phenolic content ${ }^{\mathrm{b}}$} & \multirow[t]{2}{*}{ Antioxidant activity ${ }^{\mathrm{c}}$} & \multirow{2}{*}{$\begin{array}{l}\text { Specific } \\
\text { AOX }^{d}\end{array}$} & \multicolumn{3}{|c|}{$\mathrm{IC}_{50}(\mu \mathrm{g}$ chlorogenic acid equivalent $/ \mathrm{ml})$} \\
\hline & & & & & MDA-MB-435 & MCF-7 & MCF-10A \\
\hline BY00Р4555 & White & $7962.0 \pm 251.7 f$ & $9964.5 \pm 542.4 \mathrm{~d}$ & $1.25 \mathrm{a}$ & $73.9 \pm 9.4$ & - & - \\
\hline Flame prince & Yellow & $10584.8 \pm 275.0 \mathrm{e}$ & $11453.9 \pm 510.3 \mathrm{~d}$ & $1.08 \mathrm{ab}$ & $70.0 \pm 3.8$ & $471.9 \pm 8.4$ & - \\
\hline BY98P5369 & Red & $21281.0 \pm 1047.0 \mathrm{~d}$ & $23609.4 \pm 1552.2 c$ & $1.11 \mathrm{ab}$ & $82.9 \pm 1.8$ & $378.9 \pm 23.7$ & - \\
\hline BY00P6653 & Red & $52323.6 \pm 229.7 a$ & $55560.6 \pm 2839.3 a$ & $1.06 \mathrm{ab}$ & $29.6 \pm 0.9$ & $473.5 \pm 11.1$ & $\geqslant 500$ \\
\hline Byrongold & Yellow & $21898.2 \pm 879.7 d$ & $22249.8 \pm 1428.2 c$ & $1.02 \mathrm{~b}$ & $72.6 \pm 2.0$ & $422.2 \pm 40.0$ & - \\
\hline Burgundy & Red & $23732.9 \pm 822.0 c$ & $24741.5 \pm 994.1 c$ & $1.04 \mathrm{ab}$ & $35.5 \pm 4.8$ & - & - \\
\hline Black Splendor & Red & $28989.2 \pm 455.3 b$ & $32826.1 \pm 476.6 b$ & 1.13ab & $76.1 \pm 0.3$ & $428.1 \pm 11.2$ & - \\
\hline
\end{tabular}

\footnotetext{
a Data indicates mean \pm SD of three replicates.

b Phenolics $=\mu \mathrm{g}$ chlorogenic acid eq/g freeze-dried extract.

c Antioxidant activity $=\mu \mathrm{g}$ Trolox eq/g freeze-dried extract.

d Specific antioxidant activity $=\mu \mathrm{g}$ Trolox eq/ $\mu \mathrm{g}$ chlorogenic acid eq. Means in each column followed by different letters are statistically different by Duncan's test $(p \leqslant 0.05)$
} 
(I)
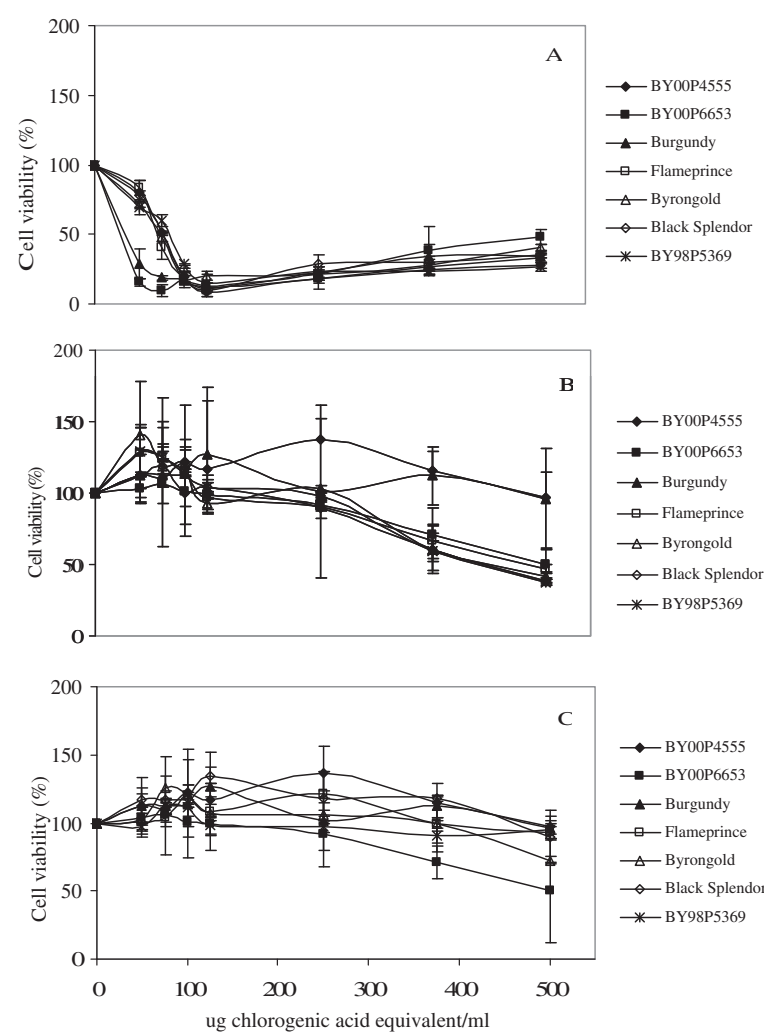

(II)
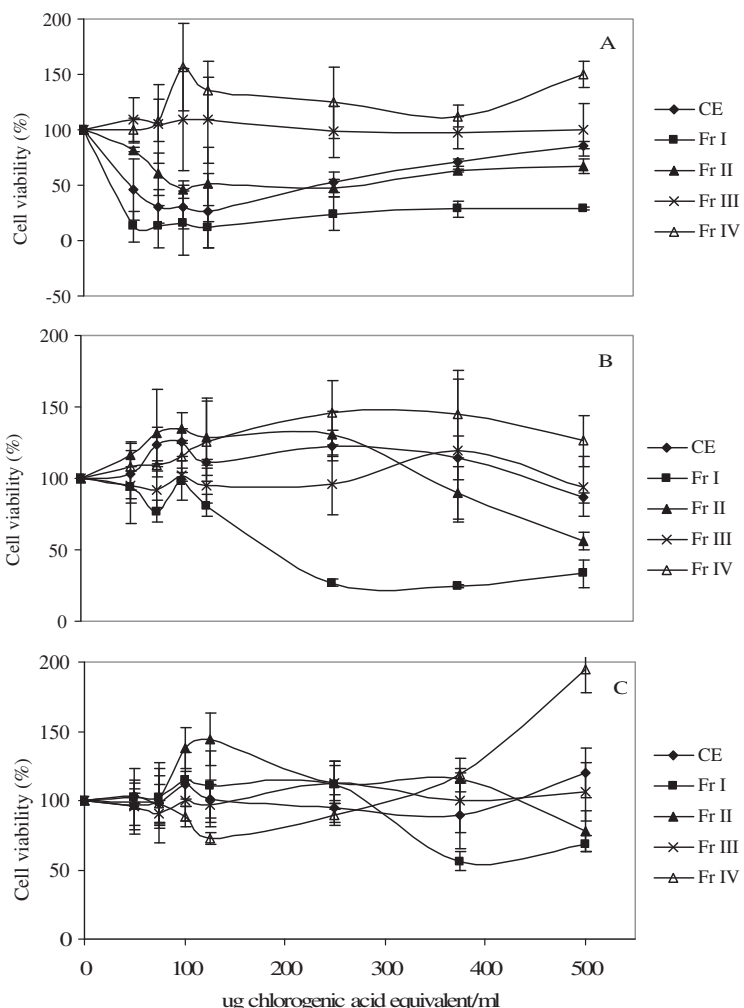

(III)

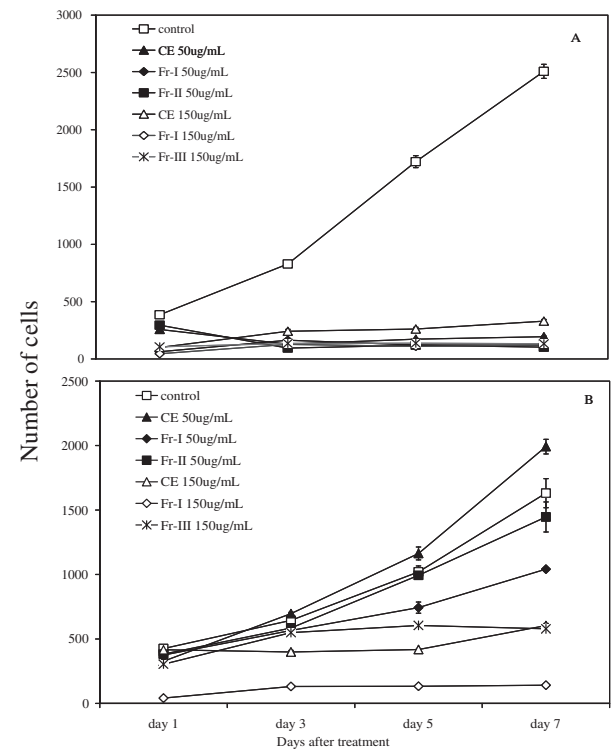

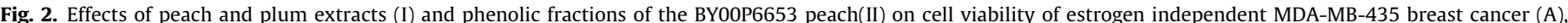

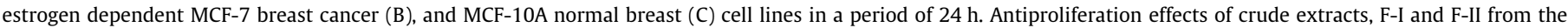

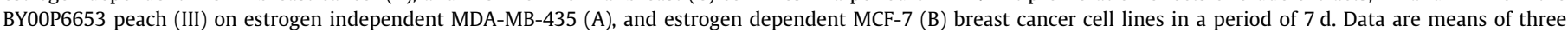
replicates \pm SD. Phenolic concentrations of crude extracts or fractions are expressed as $\mu \mathrm{g}$ chlorogenic acid equivalents/mL.

was determined for each fraction and the specific AOX was calculated (Table 2) Interestingly, there was no difference among the specific AOX for each fraction ( $1122 \mu \mathrm{g}$ Trolox/mg phenolics) suggesting the mixtures of phenolics in each fraction have similar radical scavenging properties. The red-fleshed peach BY00P6653 extract was selected for fractionation due to its potent effect on both the estrogen independent MDA-MB-435 and MCF-7 cells while having little effect on the MCF-10A cells. According to our results only the crude extract (CE) and fractions F-I and F-II showed a dose dependent response in reducing in cell viability of the MDAMB-435 cancer cell line, while fractions F-III and F-IV showed no cytotoxic effects (Fig. 2(IIA)). Furthermore, F-IV slightly increased cell viability at concentrations $>100 \mu \mathrm{g} / \mathrm{mL}$. The $\mathrm{IC}_{50}$ values followed the order $\mathrm{F}-\mathrm{I}<\mathrm{CE}<\mathrm{F}$-II (Table 2).

For the estrogen dependent MCF-7 cancer cell line, once again F-I and F-II showed a reduction in cell viability, however, this 
cytotoxic effect was observed at higher phenolic concentrations compared to MDA-MB-435 cells (Fig. 2(IIB)). Other fractions were not cytotoxic to this cancer cell line and even enhanced cell viability (CE, F-III and F-IV). The $\mathrm{IC}_{50}$ values followed the order F-I $\ll$ F-II (Table 2).

For the MCF-10A normal breast cell line, the different fractions studied did not have cytotoxic effects and there was even an increase in cell viability for F-II and F-IV (Fig. 2(IIC)). The only exception was fraction F-I which showed a cytotoxic effect at very high phenolic concentrations ( $\sim 50 \%$ at $375 \mu \mathrm{g} / \mathrm{mL}$ ).

To determine if the selected crude extract and fractions F-I and F-II inhibited cancer cell growth, we assayed the antiproliferative activities counting cells for both cancer cell lines during an incubation period of $7 \mathrm{~d}$ (Fig. 2(III)). Growth of the MDA-MB-435 cell line was completely inhibited by the crude extract and both fractions at phenolic concentrations of 50 and $150 \mu \mathrm{g} / \mathrm{mL}$. However, growth inhibition of the MCF-7 cell line depended on the fraction and amount of phenolics used. Fraction F-I showed a greater effect compared to the other treatments and at $150 \mu \mathrm{g} / \mathrm{mL}$ there was complete growth inhibition. In contrast, the crude extract promoted cell growth of MCF-7 cells at a phenolic concentration of $50 \mu \mathrm{g} / \mathrm{mL}$, confirming previous results in the present study of an enhanced cell viability for some crude extracts (Fig. 2(I)) and fractions at the lower phenolic concentration range (Fig. 2(II)). Some compounds may have a dose dependent effect on the cell growth of cancer cells, stimulating cell growth at low dose by altering the cell cycle components, while inducing cell cycle block and apoptotic cell death at high dose (Yuri et al., 2006).

In the present study there was no relationship between the specific AOX of the crude extracts or the phenolic fractions and the cell viability or antiproliferation activity (Tables 1 and 2). Other studies with fruit extracts have reported similar lack of relationship between AOX and the inhibition of proliferation on HepG2 human liver-cancer cells (Sun, Chu, Wu \& Liu, 2002), HT-29 colon cancer cells and MCF-7 breast cancer cells (Olsson et al., 2004). This has very important implications since it would be misleading to use AOX for the screening or selection of fruits and varieties or its use as a maturity index (Brovelli \& Cisneros-Zevallos, 2007) when targeting anticancer properties. More appropriate would be the use of anticancer bioassays or screening for the bioactive compounds.

\subsection{HPLC-DAD analysis of peach and plum genotypes and BY00P6653 fractions}

Phenolic identification and quantification of the genotypes were performed at $280 \mathrm{~nm}$ to verify presence of general phenolics and at $520 \mathrm{~nm}$ for anthocyanins. Comparison of retention times and UVvisible spectral data with known standards revealed the presence of a caffeic acid derivative, chlorogenic acid, cyanidin-3-glucoside, cyanidin-3-galactoside and three derivatives of quercetin (Table 3 ). A typical chromatogram profile of the peach BY00P6653 crude extract is shown in Fig. 1(II). The peach BY00P6653 showed higher concentrations of individual phenolics compared to other genotypes with exception of cyanidin-3-galactoside which is found in higher concentration on Black Splendor (Table 3). Phenolic acids such as chlorogenic acid, flavonols such as quercetin-3-glucoside, -3-galactoside, -3-rhamnoside, -3-xyloside, -3-rutinoside, and quercetin pentosyle-pentoside and anthocyanins such as cyanidin-3-glucoside, -3-galactoside, and -3-rutinoside, as well as -3-acetylglucoside have been previously reported in stone fruits (Tomás-Barberán et al., 2001; Kim et al., 2003).

According to the HPLC chromatogram, the main compounds in F-I are hydroxycinnamic acid derivatives including chlorogenic acid and a caffeic acid derivative which is likely neo-chlorogenic acid. After basic hydrolysis the two peaks disappear and a peak identified as caffeic acid appears. This fraction was the most potent at inhibiting proliferation of the estrogen dependent MDA-MB-435 and estrogen independent MCF-7 breast cancer lines. Chlorogenic acid and caffeic acid derivatives have been reported to have anticarcinogenic activity on hepatic, HL-60, U937 and jurkat cells

Table 2

Phenolic content, antioxidant activity, specific antioxidant activity and cell viability of phenolic fractions from peach BY00P6653 genotype. ${ }^{\text {a }}$

\begin{tabular}{|c|c|c|c|c|c|c|}
\hline \multirow[t]{2}{*}{ Fractions } & \multirow[t]{2}{*}{ Total phenolics ${ }^{\mathrm{b}}$} & \multirow[t]{2}{*}{ Antioxidant activity ${ }^{c}$} & \multirow[t]{2}{*}{ Specific AOX } & \multicolumn{3}{|c|}{$\underline{\mathrm{I} C_{50}(\mu \mathrm{g} \text { chlorogenic acid equivalent } / \mathrm{ml})}$} \\
\hline & & & & MDA-MB-435 & MCF-7 & MCF-10A \\
\hline $\mathrm{CE}$ & $53510.0 \pm 5718.1 \mathrm{a}$ & $64465.3 \pm 685.0 a$ & $1.21 \pm 0.10 a$ & $47.2 \pm 5.8$ & - & - \\
\hline F-I & $11609.2 \pm 4276.8 \mathrm{bc}$ & $11860.1 \pm 3239.8 c$ & $1.04 \pm 0.74 a$ & $28.6 \pm 0.2$ & $191.4 \pm 4.2$ & - \\
\hline F-II & $24815.8 \pm 1526.2 b$ & $26938.7 \pm 103.2 b$ & $1.09 \pm 0.50 a$ & $96.7 \pm 5.6$ & $>500$ & - \\
\hline F-III & $9175.8 \pm 1820.8 c$ & $9065.0 \pm 507.6 c$ & $1.01 \pm 0.18 a$ & - & - & - \\
\hline F-IV & $8797.5 \pm 491.4 c$ & $11106.5 \pm 1492.8 \mathrm{c}$ & $1.26 \pm 0.70 \mathrm{a}$ & - & - & - \\
\hline
\end{tabular}

a Data indicates mean \pm SD of three replicates.

b Phenolics $=\mu \mathrm{g}$ chlorogenic acid eq/g freeze-dried fraction extract.

c Antioxidant activity $=\mu \mathrm{g}$ Trolox eq/g freeze-dried fraction extract.

d Specific antioxidant activity $=\mu$ g Trolox eq/ $\mu$ g chlorogenic acid eq. Means in each column followed by different letters are statistically different by Duncan's test $(p \leqslant 0.05)$.

Table 3

Quantification of phenolic compounds present in peach and plum genotypes using HPLC-DAD. ${ }^{\mathrm{a}}$

\begin{tabular}{|c|c|c|c|c|c|c|c|}
\hline Genotypes & $\begin{array}{l}\text { Caffeic acid } \\
\text { derivative }^{b}\end{array}$ & $\begin{array}{l}\text { Chlorogenic } \\
\text { acid }\end{array}$ & $\begin{array}{l}\text { Cyanidin-3- } \\
\text { glucoside }\end{array}$ & $\begin{array}{l}\text { Cyanidin-3- } \\
\text { galactoside }\end{array}$ & $\begin{array}{l}\text { Quercetin } \\
\text { derivative1 }\end{array}$ & $\begin{array}{l}\text { Quercetin } \\
\text { derivative2 }\end{array}$ & $\begin{array}{l}\text { Quercetin } \\
\text { derivative3 }\end{array}$ \\
\hline BY00P4555 & $175.1 \pm 7 b$ & $532.9 \pm 20 c$ & nd & nd & nd & nd & nd \\
\hline Flameprince & $188.9 \pm 6 b$ & $794.0 \pm 35 c$ & nd & nd & nd & nd & nd \\
\hline BY98Р5369 & $194.1 \pm 7 b$ & $1489.2 \pm 181 b$ & $3554.9 \pm 147 c$ & nd & nd & nd & nd \\
\hline BY00Р6653 & $571.3 \pm 37 a$ & $3431.2 \pm 124 a$ & $10116.7 \pm 622 a$ & $1232.9 \pm 76 b$ & $678.3 \pm 37 a$ & $28.6 \pm 29 a$ & $395.6 \pm 34 a$ \\
\hline Byrongold & $140.4 \pm 15 b c$ & $1467.6 \pm 105 b$ & nd & nd & nd & nd & nd \\
\hline Burgundy & $179.5 \pm 53 b$ & $1995.1 \pm 585 b$ & $3516.8 \pm 535 c$ & $806.9 \pm 117 c$ & $55.2 \pm 13 c$ & $100.5 \pm 18 b$ & $69.2 \pm 7 b$ \\
\hline $\begin{array}{l}\text { Black } \\
\quad \text { Splendor }\end{array}$ & $94.9 \pm 49 c$ & $3774.9 \pm 427 a$ & $5530.3 \pm 781 b$ & $1729.1 \pm 141 \mathrm{a}$ & $107.8 \pm 8 b$ & $116.3 \pm 15 b$ & $50.7 \pm 2 b$ \\
\hline
\end{tabular}

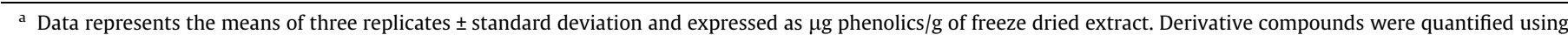
caffeic acid and quercetin standards.

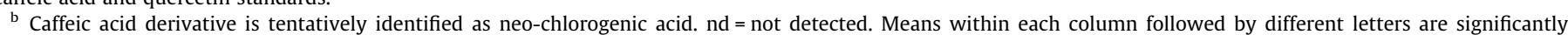
different at $p \leqslant 0.05$ with Duncan's test. 
(Park \& Schoene, 2003; Tanaka et al., 1990) and apoptosis-inducing activity on leukemia cells (Yu, G, L, R.; Rahmani, \& P.; Grant, 2002; Bandyopadhyay et al., 2004). Fraction F-II contains anthocyanins with cyanidin-3-glucoside the most abundant combined with small amounts of flavonols (Fig. 1(II)). Although catechins were expected to be in this fraction these compounds were not in sufficient concentrations to be identified. Comparison of retention times and UV-visible spectral data with known standards revealed the presence of cyanidin-3-glucoside (peak 3) and cyanidin3 -galactoside (small peak visible only at $520 \mathrm{~nm}$ ). The HPLC analysis of F-III indicated that this fraction is composed of quercetin derivative compounds (Fig. 1(II)). However, the presence of other flavonols cannot be discarded. Flavonols have high affinity for ethyl

(I)
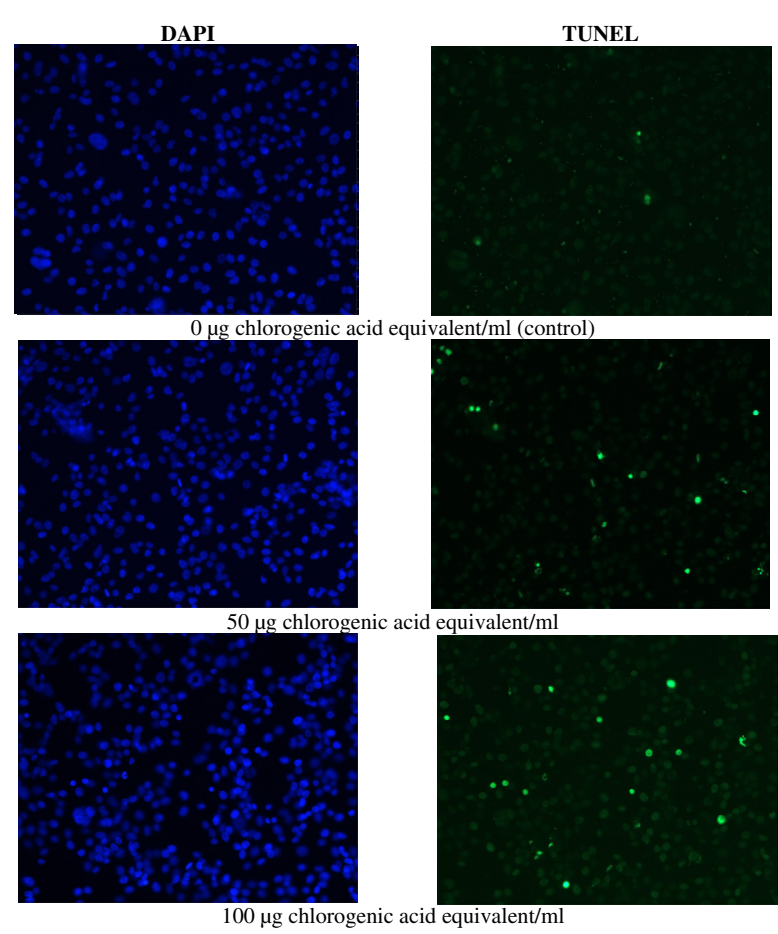

(II)

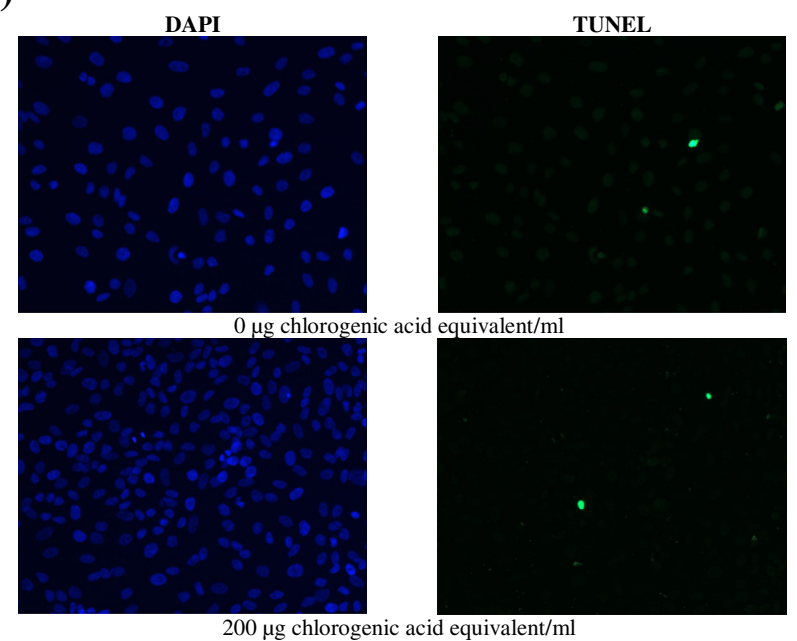

Fig. 3. TUNEL nuclear staining on estrogen independent MDA-MB-435 breast cancer (I) and MCF-10A normal breast (II) cell lines. Cells were treated with varying concentrations of total phenolics present in F-I from peach BY00P6653 and incubated for $12 \mathrm{~h}$. Cells were washed in phosphate-buffer saline, fixed and permeablized and subjected to TUNEL nuclear staining, mounted and viewed by fluorescence microscopy. acetate due to their hydrophobic characteristic (Krasteva, Nikolova, Danchev \& Nikolov, 2004). Polymer compounds, mainly polymerized anthocyanins, were the compounds present in F-IV according to the HPLC analysis (Fig. 1(II)).

The specific phenolic profile of each genotype crude extract could have determined the cytotoxic effectiveness against the cancer cells through synergistic, additive or antagonistic effects of the polyphenolic mixtures. For example, the phenolic profiles (ratios of caffeic acid derivative:chlorogenic acid:anthocyanins:quercetin derivatives) of BY00P6653 (1:6:17:2) and Burgundy (1:11:19:4) extracts were similar and these fruits showed higher cytotoxic properties (Fig. 2(I)). On the other hand, phenolic profiles of BY98P5369 (1:7:18:nd), Black Splendor (1:40:58:18), BY00P4555 (1:3:nd:nd), Byrongold (1:10:nd:nd) and Flameprince (1:4:nd:nd) were different and these fruits showed lower cytotoxic effectiveness. More work is needed to prove this hypothesis.

\subsection{Apoptosis identified by TUNEL assay}

During apoptosis, the chromatin condenses against the nuclear envelope and the DNA inside the nucleus becomes fragmented. Terminal Deoxynucleotidyl Transferase (TdT) when used with a fluorescent marker allows detection of cells with apoptotic DNA fragmentation. TdT is an enzyme that catalyzes the repetitive addition of dUTPs (Alexa 488) to the 3-OH ends of a DNA fragment. In TUNEL analysis, the fluorescently conjugated dUTP are added to the 3-OH groups of the DNA fragments making the apoptotic cells visible by fluorescent microscopy (Jewell \& Mastro, 2002).

After incubation with $50 \mu \mathrm{g}$ chlorogenic acid/mL of F-I for $12 \mathrm{~h}$, TUNEL assay was performed to visualize apoptosis in MDAMB-435 estrogen receptor-negative cells (Fig. 3(I)) and MCF-10A normal cells (Fig. 3(II)). Control or untreated cells were assayed as well. Control MDA-MB-435 cells did not show a positive TUNEL reaction, whereas the cells treated with F-I (50 and $100 \mu \mathrm{g} / \mathrm{mL}$ ) incorporated the labeled nucleotide into the fragmented DNA (Fig. 3(I)). On the other hand MCF-10A cell did not show a positive reaction neither for treated cells $(200 \mu \mathrm{g} / \mathrm{mL})$ nor for the control cells (Fig. 3(II)).

\section{Conclusions}

In summary, polyphenolic extracts from peach and plum genotypes showed selective cytotoxicity against the estrogen independent MDA-MB-435 breast cancer cells compared to the estrogen dependent MCF-7 cells and small or no effects on MCF-10A non-cancerous breast cell line. Polyphenolic profiles for the selected stone fruit genotypes had varying degrees of phenolic mixtures. Chlorogenic acid and a caffeic acid derivative present in F-I fraction of the BY00P6653 peach genotype was the most effective among the phenolic fractions in reducing cell viability of both cancer cell lines, with little effect on the normal cells. Furthermore, F-I showed antiproliferative activity in both cancer cell lines. The Tunel assay confirmed that F-I induced apoptotic cell DNA fragmentation in MDA-MB-435 cancer cells while not affecting normal cells. This study shows that selected stone fruits can be added to the list of fruits with cytotoxic properties against breast cancer cells while not affecting normal cells; however, further work is needed to elucidate the molecular mechanism involved in induced apoptosis by stone fruit polyphenols.

\section{Acknowledgements}

This material is based upon work supported by the Cooperative State Research, Education, and Extension Service, U.S. Department of Agriculture under Agreement No. 2004-34402-14768 "Designing 
Foods for Health" through the Vegetable \& Fruit Improvement Center, Texas AgriLife Research.

\section{References}

Bandyopadhyay, G., Biswas, T., Roy, K. C., Mandal, S., Mandal, C., Pal, B. C., et al. (2004). Chlorogenic acid inhibits Bcr-Abl tyrosine kinase and triggers p38 mitogen-activated protein kinase-dependent apoptosis in chronic myelogenous leukemic cells. Blood, 104(8), 2514-2522.

Brovelli, E., \& Cisneros-Zevallos, L. (2007). Horticultural maturity revisited: from peaches to Echinacea. Fresh Produce, 1(1), 1-3.

Cevallos-Casals, B. A., \& Cisneros-Zevallos, L. (2003). Stoichiometric and kinetic studies of phenolic antioxidants from Andean purple corn and red-fleshed sweetpotato. Journal of Agriculture and Food Chemistry, 51, 3313-3319.

Edenharder, R., Krieg, H., Kottgen, V., \& Platt, K. L. (2003). Inhibition of clastogenicity of benzo[a]pyrene and of its trans-7,8-dihydrodiol in mice in vivo by fruit, vegetables, and flavonoids. Mutation Research, 537, 169-181.

Ferguson, P., Kurowska, E., Freeman, D. J., Chambers, A. F., \& Koropatnick, D. J. (2004). A flavonoid fraction from cranberry extract inhibits proliferation of human tumor cell lines. Nutrition and Cancer, 134(6), 1529-1535.

Fujii, T., Ikami, T., Xu, J. W., \& Ikeda, K. (2006). Prune extract (Prunus domestica L.) suppresses the proliferations and induces de apoptosis of human colon carcinoma Caco-2. Journal of Nutritional Science and Vitaminology, 52, 189-191.

Hakimuddin, F., Paliyath, G., \& Meckling, K. (2004). Selective cytotoxicity of a red grape wine flavonoid fraction against MCF-7 cells. Breast Cancer Research, 85, 65-79.

Hertog, M. G. L, Kromhout, D., Aravanis, C., Blackburn, H., Buzina, R., Fidanza, F. et al. (1995). Flavonoid intake and long-term risk of coronary heart disease and cancer in the seven countries study. Archives of Internal Medicine, 155, 381-386.

Jewell, M., \& Mastro, A. M. (2002). Using Terminal Deoxynucleotidyl Transferase (TdT) enzyme to detect TUNEL-positive, GFP-expressing apoptotic cells. Applications in Cell Biology, 3, 13-14.

Kamei, H., Kojima, T., Hasegawa, M., Koide, T., Umeda, T., Yukawa, T., et al. (1995). Suppression of tumor cells by anthocyanins in vitro. Cancer Investigation, 13, 590-594.

Kim, D. O., Chun, K., Kim, Y. J., Moon, H., \& Lee, C. Y. (2003). Quantification of polyphenolics and their antioxidant capacity in fresh plums. Journal of Agriculture and Food Chemistry, 51, 6509-6515.

Krasteva, I., Nikolova, I., Danchev, N., \& Nikolov, S. (2004). Phytochemical analysis of ethyl acetate extract from Astragalus corniculatus Bieb. and brain antihypoxic activity. Acta Pharmaceutica-Zagreb, 54, 151-156.

Liu, R. H., Liu, J., \& Chen, B. (2005). Apples prevent mammary tumors in rats. Journal of Agriculture and Food Chemistry, 53(6), 2341-2343.

Miyazawa, M., \& Hisama, M. (2003). Antimutagenic activity of phenylpropanoids from clove (Syzygium aromaticum). Journal of Agriculture and Food Chemistry, 51, 6413-6422.
Mosmann, T. (1983). Rapid colorimetric assay for cellular growth and survival: Application to proliferation and cytotoxicity assays. Journal of Immunological Methods, 65, 55-63.

Olsson, M. E., Gustavsson, K. E., Andersson, S., Nilsson, A., \& Duan, R. D. (2004) Inhibition of cancer cell proliferation in vitro by fruit and berry extracts and correlations with antioxidant levels. Journal of Agriculture and Food Chemistry, 52(24), 7264-7271.

Oszmianski, J., Ramos, T., \& Bourzeix, M. (1988). Fractionation of phenolic compounds in red wine. American Journal of Enology and Viticulture, 39(3) 259-262.

Park, J. B., \& Schoene, N. (2003). N-Caffeoyltyramine arrests growth of U937 and Jurkat cells by inhibiting protein tyrosine phosphorylation and inducing caspase 3. Cancer Letters, 202(2), 161-171.

Parkin, D. M. (2004). International variation. Oncogene, 23, 6329-6340.

Pasqualini, J. R. (2004). The selective estrogen enzyme modulators in breast cancer: A review. Biochimica et Biophysica Acta, 1654, 123-143.

Ramos, S., Alía, M., Bravo, L., \& Goya, L. (2005). Comparative effects of food-derived polyphenols on the viability and apoptosis of a human hepatoma cell line (HepG2). Journal of Agriculture and Food Chemistry, 53, 1271-1280.

Saleem, A., Husheem, M., Harkonen, P., \& Pihlaja, K. (2002). Inhibition of cancer cell growth by crude extract and the phenolics of Terminalia chebula retz. fruit. Journal of Ethnopharmacology, 81(3), 327-336.

Son, Y. O., Kim, J., Lim, J. C., Chung, Y., Chung, G. H., \& Lee, J. C. (2003). Ripe fruits of Solanum nigrum L. inhibits cell growth and induces apoptosis in MCF-7 cells. Food and Chemical Toxicology, 41, 1421-1428.

Sun, J., Chu, Y. F., Wu, X., \& Liu, R. H. (2002). Antioxidant and proliferative activities of common fruits. Journal of Agricultural and Food Chemistry, 50, 7449-7454.

Tanaka, T., Nishikawa, A., Shima, H., Sugie, S., Shinoda, T., Yoshimi, N., et al. (1990). Inhibitory effects of chlorogenic acid, reserpine, polyprenoic acid (E-5166), or coffee on hepatocarcinogenesis in rats and hamsters. Basic Life Sciences, 52, 429-440.

Tomás-Barberán, F. A., Gil, M. I., Cremin, P., Waterhouse, A. L., Hess-Pierce, B., \& Kader, A. A. (2001). HPLC-DAD-ESIMS analysis of phenolic compounds in nectarines, peaches, and plums. Journal of Agriculture and Food Chemistry, 49, 4748-4760.

Vizzotto, M., Cisneros-Zevallos, L., Byrne, D., Ramming, D. W., \& Okie, W. R. (2007) Large variation found in the phytochemical and antioxidant activity of peach and plum germplasm. Journal of the American Society for Horticultural Science, $132,1-7$.

Yu, C., Krystal, G., Varticovksi, L., McKinstry, R., Rahmani, M., Dent, P., et al. (2002). Pharmacologic mitogen-activated protein/extracellular signal-regulated kinase kinase/mitogen-activated protein kinase inhibitors interact synergistically with STI571 to induce apoptosis in Bcr/Abl-expressing human leukemia cells. Cancer Research, 62(1), 188-199.

Yuri, T., Tsukamoto, R., Miki, K., Uehara, N., Matsouka, Y., \& Tsubura, A. (2006) Biphasic effects of zeranol on the growth of estrogen receptor-positive human breast carcinoma cells. Oncology Reports, 16, 1307-1312. 